\title{
Contribution of Legumes on Phosphoric Absorption by Panicum maximum cv Riversdale in Intercropping System
}

\author{
Sajimin $^{1}$, Purwantari ND ${ }^{1}$, Sugoro $I^{2}$ \\ ${ }^{1}$ Indonesian Research Institue of Animal Production, Ciawi PO Box 221, Bogor Indonesia \\ ${ }^{2}$ PATIR BATAN, Jakarta Indonesia \\ E-mail:djiemin@yahoo.com
}

(received 24-06-2016; revised 23-08-2016; accepted 29-08-2016)

\begin{abstract}
ABSTRAK
Sajimin, Purwantari ND, Sugoro I. 2016. Kontribusi tanaman legume dalam peningkatan serapan fosfor rumput Panicum maximum cv Riversdale dengan sistem tanam tumpang sari. JITV 21(3): 151-158. DOI: http://dx.doi.org/10.14334/jitv.v21i3.1520

Ketersediaan fosfor (P) dalam tanah sebagai unsur hara yang sifatnya mobil mempengaruhi pertumbuhan tanaman. Tujuan dari penelitian ini untuk meningkatkan ketersediaan fosfor dan produksi rumput Panicum maximum cv Riversdale yang ditanam tumpang sari dengan tanaman leguminosa. Percobaan dirancang secara acak lengkap dengan lima perlakuan dan lima ulangan yaitu : A. Gliricidia sepium + P. maximum; B. Calliandra calothyrsus + P. maximum; C. Leucaena leucocephala cv Taramba + $P$. maximum; D. Calopogonium mucunoides + P. maximum; E. P.maximum (kontrol negatif). Tanaman tumpang sari ditumbuhi pada pot dengan diberi pembatas yang dilubangi untuk pertumbuhan akar tanaman leguminosa di media rumput. Setelah tiga bulan tumbuh pada area tanaman leguminosa isotop ${ }^{32} \mathrm{P}$ diinjeksi sebanyak $50 \mathrm{ml}(11,23 \mu \mathrm{ci} / \mathrm{ml})$. Setelah inkubasi selama 21 hari sampel tanah pada kedua area dan kedua tanaman dikumpulkan untuk analisis kadar isotop pada tanaman dan translokasi fosfor dideteksi dengan menggunakan perunut isotop ${ }^{32} \mathrm{P}$. Produksi hijauan juga diamati pada ke dua tanaman. Hasil penelitian menunjukkan kadar fosfor tanah rumput dipengaruhi jenis legum, $G$ sepium dan $C$. callothyrsus nyata lebih tinggi terhadap kontrol, sedangkan $L$. leucocephala tidak berbeda nyata, dan kadar P nyata lebih rendah pada $C$. mucunoides. Deteksi ${ }^{32} \mathrm{P}$ menunjukkan akar legum yang terintegrasi di daerah rumput memindahkan $\mathrm{P}$. Produksi rumput $P$. maximum dengan sistem tumpang sari secara nyata meningkat pada G. sepium, secara tidak nyata pada L. leucocephala dan C. callothyrsus dibandingkan perlakuan kontrol, sedangkan $C$. mисunoides turun $26,2 \%$ walaupun tidak berbeda nyata. Data dari tumpangsari $C$. mucunoides menunjukkan produksi hijauan legum tertinggi. Dapat disimpulkan bahwa ketersediaan fosfor dan produksi rumput dapat ditingkatkan dengan sistem tumpang sari dengan legum. Jenis legum mempengaruhi efektivitas.
\end{abstract}

Kata Kunci: Produksi Hijauan, Leguminosa, Panicum maximum, Tumpang Sari, Isotop ${ }^{32} \mathrm{P}$

\begin{abstract}
Sajimin, Purwantari ND, Sugoro I. 2016. Contribution of legumes on phosphoric absorption by Panicum maximum cv Riversdale in intercropping system. JITV 21(3): 151-158. DOI: http://dx.doi.org/10.14334/jitv.v21i3.1520

Phosphorus availability in soil as a mobile mineral influences forage growth. The purpose of doing this research is to enhance the soil phosphorus availability and grass production of Panicum maximum cv Riversdale by intercropping system with legums. The experiment was conducted based on with randomized design with five treatments of mixcropping of: (i) Gliricidia sepium + P. maximum; (ii) Calliandra calothyrsus $+P$. maximum; (iii) Leucaena leucocephala $\mathrm{cv}$ Taramba $+P$. maximum; (iv) Calopogonium mucunoides $+P$. maximum; (v) P. maximum as negative control. Plants were grown in pots with split-root technique using partition with a whole to allow some legume roots grew in the grass side. After growing for three months, on the legume areas ${ }^{32} \mathrm{P}$ isotop solution was injected for $50 \mathrm{ml}(11.23 \mu \mathrm{ci} / \mathrm{ml})$. After 21 days incubation samples were collected from both soil areas and both plants. The translocation of ${ }^{32} \mathrm{P}$ was determined using geiger counter from legumes into the grass and the concentration of ${ }^{32} \mathrm{P}$ was also determined in all plants. Forage productions was determined both in the legumes and grass. Result showed that soil phosphorus concentration in the grass area was significantly improved by intercropping with $G$. sepium and $C$. callothyrsus, while the one with $L$. leucocephala was similar, and the one with $C$. mucunoides was significantly lower than that of negative control (without legume). Detection of ${ }^{32} \mathrm{P}$ showed that there was $\mathrm{P}$ translocation in the system. P. maximum grass production depending on kind of legumes $(\mathrm{P}<0.05)$ those with $G$. sepium was significantly higher, $L$. leucocephala and $C$. callothyrsus were not significantly higher, while the one with $C$. mucunoides was $26.2 \%$ lower from the control although not significantly. However, C. mucunoides produced the highest forage from the legume plant. It is concluded that grass-legume intercropping had a positive impact on phosphorus soil concentration in the grass area and grass production. Kind of legumes influenced the effectivity.
\end{abstract}

Key Words: Forage Production, Legume, Panicum maximum, Intercropping, ${ }^{32} \mathrm{P}$ Isotop 


\section{INTRODUCTION}

Developing forage plantations in the marginal areas such as acid areas is not optimal for crop production, but potentially important for feed forage. Horst et al. (2006) reported that acid soil reaches 1.7 billion hectars and $43 \%$ is in tropical area. In Indonesia, acid land reaches 102.8 - 107.4 million ha and has not been used optimally (Mulyani et al. 2004; Agus et al. 2015). Farmers in Indonesia used excessive phosphorus chemical fertilizer to enhance the crop production for $100 \mathrm{~kg} \mathrm{TSP} / \mathrm{ha}$ of paddy field. In the long term excessive $\mathrm{P}$ application might form cementing layer on land surface (Karama et al. 1991; Saidu \& Abayomi 2015).

Phosphorus (P) is absorbed as orthophosphate ions is an important element for growing plant cells for phospholipid in the cell membrane, for accumulation and releasing cell energy in metabolism and as sugarphosphate in nucleotides for genetic information (Franzini et al. 2009). P deficiency showed retarded growth in crops and reddish leaves due to the increase of anthocyanin. P is important for metabolism including cell division, respiration, and photosynthesis (Richardson et al. 2009). Hakim et al. (1986) suggests that in high acidity soil $(\mathrm{pH}<5)$, phosphate ions are easily binded with $\mathrm{Al}$, $\mathrm{Fe}$ or $\mathrm{Mn}$ forming insoluble compounds that reduce the $\mathrm{P}$ availability. Together with $\mathrm{N}, \mathrm{P}$ is important for forage quality and the availability are influenced by microbial activities surrounding the roots (Guo et al. 2000; Alan et al. 2009).

Good combination of intercropping or mixed cropping system of legumes and grass increases the grass production as well as reduce the use of $\mathrm{N}$ and $\mathrm{P}$ inorganic fertilizers or resultes friendly ecosystems (Exner et al. 1999). Intercropping of legumes and maize increases $\mathrm{N}$ in the soil (Li et al. 2003; Eskandori et al. 2009; Belel et al. 2014). The intercropping of legumes and elephant grass in the contour system also reduce the erotion and increase the production and forage quality (Anantawiroon et al. 2006; Mutegi et al. 2008).

Intercropping of cowpea-maize improves soil phosphorus availability and maize yields (Latati et al. 2014). Other researchers also reported that the non legume plants get phosphorus from legumes (Elgersma et al. 2000). Transportation of phosphorous from the legumes to the Panicum grass may be traced using radioisotope of ${ }^{32} \mathrm{P}$ injected in the legume areas. The intercropping system might be carried out using partition to separate both plants except that some of legume roots were in the grass area. The roots may translocate the radioisotope from the legume areas. Therefore, the transportation of ${ }^{32} \mathrm{P}$ may be traced.

This research was aimed to increase the yield of the Panicum maximum (Panicum grass) in acid soil by intercropping with kinds of legumes incorporated with ${ }^{32} \mathrm{P}$.

\section{MATERIALS AND METHODS}

\section{Kinds of soils}

This study was conducted in the greenhouse of IRIAP, Ciawi-Bogor using red-yellow podsolit soil collected from experimental garden. Soil was dried and sieved by $2 \mathrm{~mm}$ and then its nutrient content was analyzed. The results showed that soil consisted of $7 \%$ sand texture, $64 \%$ ash, and $29 \%$ clay at $\mathrm{pH}$ of 4.6 . The organic and inorganic elements were $2.39 \% \mathrm{C}, 0.097 \%$ $\mathrm{N}, 61.67$ ppm P, 0.08 ppm K, 5.72 ppm Ca, 1.09 ppm $\mathrm{Mg}$ and $0.31 \mathrm{ppm} \mathrm{Na}$.

\section{Design of experiment}

This study employed completely randomized design with five treatments and five repitations as follows:

a) Gliricidia sepium + Panicum maximum $\mathrm{cv}$ Riversdale

b) Calliandra calothyrsus $+P$. maximum $\mathrm{cv}$ Riversdale

c) Leucaena leucocephala cv Taramba $+P$. maximum cv Riversdale

d) Calopogonium mucunoides $+P$. maximum $\mathrm{cv}$ Riversdale

e) $P$. maximum cv Riversdale only as negative control

If there were significant difference in analyses of variance, data were further analyzed with Duncan (Gomez \& Gomez 1984).

\section{Intercropping system}

Intercropping system used in this study was SplitRoot Technique (Catchpoole 1988) in combination with method by Xiao et al. (2004). One pol grass and one pol of each legume were planted in a pot containing $32 \mathrm{~kg}$ dry weight of soil and divided by a diagonally fiber partition. The partition had a hole so that the legume root partially passed through the hole in the area of the grass plant (Figure 1). 
a.

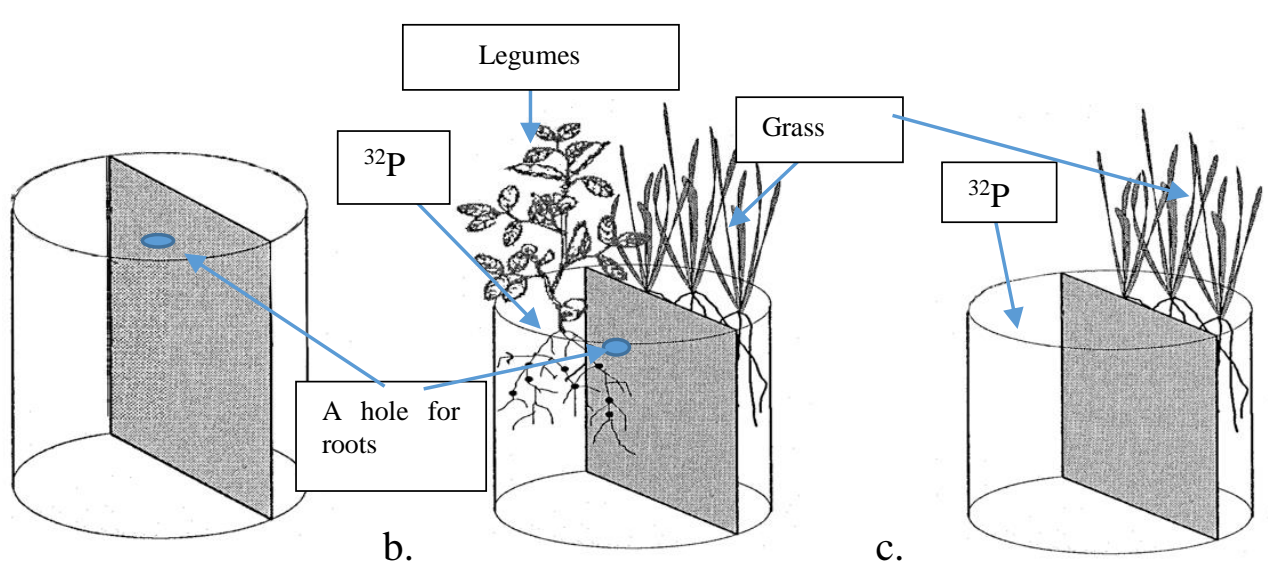

Figure 1. Position of the plants and ${ }^{32} \mathrm{P}$ injection in the pots with the fiber partition. (a) Pots before the plants growing; (b) Pots after the plants growing, some of legume roots grew through the hole to the grass area; (c) Control pots without legumes.

\section{Aplication and detection of ${ }^{32} \mathbf{P}$}

Radioisotope ${ }^{32} \mathrm{P}$ as $\mathrm{KH}_{2}{ }^{32} \mathrm{PO}_{4}$ solution was injected $50 \mathrm{~mL}(561.5 \mu \mathrm{ci} /$ pots $)$ in the soil area of legumes at three months growth. The transportation of the ${ }^{32} \mathrm{P}$ was traced using Geiger Muller all on the surface soil and part of the plants in IRIAP, while the concentration of ${ }^{32} \mathrm{P}$ was determined in the laboratory of National Nuclear Energy Agency of Indonesia. Distribution of the radio isotope in the stem pit and leaves of legumes was detected after the injection for 14 days. All data were collected for phosphorus recovery determination.

Total phosphorus content in the soil before and after the experiment was determined in Indonesian Center for Agricultural Land Resources Research and Development. Variables determined for forage production were plant height, number of shoots and bundles respectively for the legumes and the Panicum grass, dry weight of nodules, dry weight of roots, and forage production.

\section{RESULTS AND DISCUSSIONS}

Soil phosphorus availability. $\mathrm{P}$ availability of soils for grass or legumes was determined after the plants grew, but before P-isotope was introduced (Table 1). The soil planted only with $P$. maximum (control) at 64.0 ppm was lower than those integrated with legume roots of G. sepium (74.3 ppm) and C. calothyrsus (70.7 ppm), similar of L. leucocephala (65.7 ppm), but higher than the one with $C$. mucunoides $(56.7 \mathrm{ppm})$. The $\mathrm{P}$ availability in soils of $G$. sepium and $C$. calothyrsus were not significantly different. P-availability of soils planted with legume seemed higher than that of grass only (negative control). The P-availability in soils were influenced by legume intercropping and also kinds of legumes incorporated, the lower $\mathrm{P}$ in the legume area affected the lower $\mathrm{P}$ in the grass area. The highest $\mathrm{P}$ was observed from G. sepium and C. calothyrsus, followed by $L$. leucocephala $c v$. Tarramba, and negative control. $\mathrm{P}$ in the grass area intercropped with C. mucunoides was significantly lower than that of the negative control.

The increase of P-availability in the grass area was in agreement with the one reported by Latati et al. (2014) that discover the increase of P in maize soil area integrated with cowpea. The lowest $\mathrm{P}$ in the legume soil area might be related with the P- consumption for the leave production. Leave production of $C$. mucunoides is relatively high. The lowest $\mathrm{P}$-availability in the grass area integrated with $C$. mucunoides was not only affected by the low $\mathrm{P}$ in the legume area, but might be also influenced the availability of its root in the grass area. The effectiveness of P-transportation from legume soil area to the grass area was then detected by the transportation of ${ }^{32} \mathrm{P}$ isotop.

\section{Recovery of ${ }^{32} \mathbf{P}$ on the legumes and grass}

Data of ${ }^{32} \mathrm{P}$ tracers in each repeatation were similar, therefore detection of ${ }^{32} \mathrm{P}$ using Geiger Muller counter was used to detect the $\mathrm{P}$ transportation from legumes soils to grasses's and part of both plants (Table 2). The isotop was transported from the legume soils in the whole parts of legumes and transported to grass soils and parts of grass. The transportation from legumes to grass areas was more influenced by kind of legumes than those from the concentration of ${ }^{32} \mathrm{P}$ in the soils like the one observed in L. leucocephala.

The injection of ${ }^{32} \mathrm{P}$ was carried out after the legumes producing roots in the grass areas. The ${ }^{32} \mathrm{P}$ was more detected in the legumes than that in grass except for $C$. mucunoides. The stem of L. leucocephala had the highest traced, while from other parts and other 
legumes, as well as grass. The highest trace was observed in G. sepium dan C. mucunoides.

Data of tracers showed that ${ }^{32} \mathrm{P}$ G.sepium was higher in its stem than that in its leave tips. ${ }^{32} \mathrm{P}$ has more mobility in the stem than in the leaves. After pruning plants usually will grow again and the ${ }^{32} \mathrm{P}$ will be spread out following the cell division (Kalaivanan et al. 2014). The Geiger Muller counter is more to detect the isotop transportation in the plant parts, therefore to observe the effect of the ${ }^{32} \mathrm{P}$ injection to the legumes and grass the concentration of ${ }^{32} \mathrm{P}$ of all plants were detected (Table 3).

Table 1. $P$ availabilities on soils grown with legumes and on grass areas integrated with roots of legumes

\begin{tabular}{lcc}
\hline \hline Kinds of legume roots integrated with P. maximum & P on areas of legume soil $(\mathrm{ppm})$ & P on areas of grass soils $(\mathrm{ppm})$ \\
\hline G. sepium & $118.3^{\mathrm{a}}$ & $74.3^{\mathrm{a}}$ \\
L. leucocephala cv. Tarramba & $74.7^{\mathrm{c}}$ & $65.7^{\mathrm{b}}$ \\
C.calothyrsus & $107.3^{\mathrm{b}}$ & $70.8^{\mathrm{a}}$ \\
C. mucunoides & $78.7^{\mathrm{c}}$ & $56.7^{\mathrm{c}}$ \\
Control & $\mathrm{ND}$ & $64.0^{\mathrm{b}}$ \\
\hline
\end{tabular}

Different superscript letters in the same column show significant difference $(\mathrm{P}<0.05)$; ND was not determined.

Table 2. Distribution of 32P on legumes and grasses and their soil surface

\begin{tabular}{|c|c|c|c|c|}
\hline \multirow{2}{*}{ Kind of legumes } & \multicolumn{4}{|c|}{ Recovery of ${ }^{32} \mathrm{P}$ on legume soils and plants ( $\left.\mu \mathrm{ci} / \mathrm{g} . \mathrm{min}\right)$} \\
\hline & Soil surface & Stem & Leaves & Leave tips \\
\hline G. sepium & $3391.7^{\mathrm{ab}}$ & $366.7^{\mathrm{ab}}$ & $216.7^{\mathrm{a}}$ & $158.3^{\mathrm{a}}$ \\
\hline L. leucocephala & $8000.0^{\mathrm{a}}$ & $583.3^{\mathrm{a}}$ & $158.3^{\mathrm{b}}$ & $100.0^{\mathrm{b}}$ \\
\hline C. callohyrsus & $1116.7^{\mathrm{b}}$ & $283.3^{b}$ & $183.3^{\mathrm{b}}$ & $133.3^{\mathrm{a}}$ \\
\hline C. mucunoides & $1250.0^{\mathrm{b}}$ & $350.0^{\mathrm{ab}}$ & $337.5^{\mathrm{a}}$ & $150.0^{\mathrm{a}}$ \\
\hline \multirow[t]{2}{*}{ Control } & $2333.3^{\mathrm{ab}}$ & ND & ND & ND \\
\hline & \multicolumn{4}{|c|}{ Recovery of ${ }^{32} \mathrm{P}$ on grass soils and grass ( $\left.\mu \mathrm{ci} / \mathrm{g} . \mathrm{min}\right)$} \\
\hline G. sepium & $91.7^{\mathrm{b}}$ & $216.7^{\mathrm{b}}$ & $208.3^{\mathrm{ab}}$ & $233.3^{\mathrm{a}}$ \\
\hline L. leucocephala & $91.7^{\mathrm{b}}$ & $258.3^{\mathrm{b}}$ & $250.0^{\mathrm{ab}}$ & $183.3^{\mathrm{b}}$ \\
\hline C. callohyrsus & $166.7^{\mathrm{a}}$ & $275.0^{\mathrm{b}}$ & $166.7^{\mathrm{b}}$ & $175.0^{\mathrm{b}}$ \\
\hline C. mucunoides & $150.0^{\mathrm{a}}$ & $350.0^{\mathrm{a}}$ & $300.0^{\mathrm{a}}$ & $275.0^{\mathrm{a}}$ \\
\hline Control & ND & ND & ND & ND \\
\hline
\end{tabular}

Different superscript letters in the same column show significant difference $(\mathrm{P}<0.05)$;

ND was not determined. Traced of 32P was carried out by Geiger Muller.

Table 3. Trace of 32P ( $\mu \mathrm{ci} / \mathrm{g}$ plants) on the legumes and grasses

\begin{tabular}{lcc}
\hline \hline Kind of legumes & Legumes & Grasses \\
\hline G. sepium & $839^{\mathrm{d}}$ & $11133^{\mathrm{a}}$ \\
L.leucocephala & $4945^{\mathrm{b}}$ & $9107^{\mathrm{a}}$ \\
C. calothyrsus & $2361^{\mathrm{c}}$ & $8043^{\mathrm{a}}$ \\
C. mucunoides & $14540^{\mathrm{a}}$ & $9673^{\mathrm{a}}$ \\
Control & No plants & $71^{\mathrm{b}}$ \\
\hline
\end{tabular}

Different superscript letters in the same column show significant difference $(\mathrm{P}<0.05)$. 
Each legume had significant difference of ${ }^{32} \mathrm{P}$ concentration. The highest concentration of ${ }^{32} \mathrm{P}$ on the legumes was observed at $C$. mucunoides followed by $L$. leucocephala, C. calothyrsus, while G. sepium had the lowest concentration (Table 3). Although no legume was grown in the control, ${ }^{32} \mathrm{P}$ was detected in the grass with very low concentration. This very low concentration resulted in none significant different at ${ }^{32} \mathrm{P}$ concentration in each grass intercropped, although there was $28 \%$ different from the one integrated with G. sepium vs with $C$. calothyrsus. The highest ${ }^{32} \mathrm{P}$ concentration in the grass was observed at the one intercropped with $G$. sepium root $(11133 \mu \mathrm{ci} / \mathrm{g})$, followed by $C$. mucunoides $(9673 \mu \mathrm{ci} / \mathrm{g}), \quad L$. leucocephala $(9107 \mu \mathrm{ci} / \mathrm{g})$ and C. calothyrsus (8043 $\mu \mathrm{ci} / \mathrm{g})$. Contribution of ${ }^{32} \mathrm{P}$ from the legumes into the grass depended on kinds of legumes. The grass integrated with G. sepium showed certain condition that the ${ }^{32} \mathrm{P}$ was low in the legume but it was high in the grass. The relation of the $\mathrm{P}$ concentration toward the grass production will be discussed in the grass production paragraph. Anantawiroon et al. (2006) reported that kinds of legumes in the intercropping system resulted in different production and quality of Napier grass.

Compared to the control the grass with legume root integration had higher ${ }^{32} \mathrm{P}$. This result is in agreement with that reported by Richardson et al. (2009) that ${ }^{32} \mathrm{P}$ from legume areas is trans located to barley. The translocation is influenced by the legume root amount in the barley areas and legume morphology. The ${ }^{32} \mathrm{P}$ in the grass areas influences the grass phosphoric absorbtion.

\section{Root nodules and weights}

Each legume function in nitrogen fixation had different root nodules in shapes, location in the roots and numbers (Table 4). Numbers of the nodules was expressed in weight, higher weight shows higher numbers. The heighest weight nodules were observed in L. leucocephala, however, they were only in the center (primary root). Therefore, the effectivity of the noodles only functioned for the legume not for the grass. Nodules of G. sepium spread over primary and secondary roots in high number including in grass area, therefore it would influence better for the grass production. The root nodules of $C$. mucunoides were quite a lot in the grass area, however, their quality was not as good. The color was black. The best quality of root nodules for nitrogen fixation is when they are pink and large.

Data of Table 5 shows that legume roots grew together with grass roots. This rhizofer system helps the translocation of nutrients including P from legume areas to grass area. The root nodules of the legumes especially those in the grass area will also help the nitrogen fixation for the grass growth. Rhizosfer zone in the grass areas will be influenced by the root legume structure (Fustec et al. 2010), while root activity significantly influences the physical, chemical and

Table 4. Root nodules of the legumes

\begin{tabular}{|c|c|c|c|c|}
\hline \multirow{2}{*}{ Kind of legumes } & \multicolumn{2}{|c|}{ Weight (g/plants) } & \multirow{2}{*}{ Shape and colours } & \multirow{2}{*}{ Position } \\
\hline & Legume areas & Grass areas & & \\
\hline G.sepium & $1.38^{\mathrm{b}}$ & $0.45^{b}$ & Round, cream & Spread \\
\hline L.leucocephala & $3.94^{\mathrm{a}}$ & $0.06^{\mathrm{c}}$ & Large, pink & Centre \\
\hline C. calothyrsus & $0.74^{\mathrm{c}}$ & $0.10^{\mathrm{c}}$ & Spherical, pink & Centre \\
\hline C.mucunoides & $1.51^{\mathrm{b}}$ & $0.71^{\mathrm{a}}$ & Small, round, black & Spread \\
\hline
\end{tabular}

Different superscript letters in the same column show significant difference $(\mathrm{P}<0.05)$. Centre position means the noodles were only observed in the primary roots.

Table 5. The weight of legume and grass roots

\begin{tabular}{lccc}
\hline Kind of legumes & \multicolumn{2}{c}{ Weight of legume roots $(\mathrm{g})$} & Weight of grass roots $(\mathrm{g})$ \\
\hline G. sepium & Legume areas & Grass areas & $135.0^{\mathrm{a}}$ \\
L. leucocephala & $81.2^{\mathrm{a}}$ & $9.0^{\mathrm{c}}$ & $150.5^{\mathrm{a}}$ \\
C. calothyrsus & $60.0^{\mathrm{b}}$ & $27.5^{\mathrm{b}}$ & $34.6^{\mathrm{c}}$ \\
C. mucunoides & $14.0^{\mathrm{c}}$ & $2.8^{\mathrm{d}}$ & $60.0^{\mathrm{b}}$ \\
\hline
\end{tabular}

Different superscript letters in the same column show significant difference $(\mathrm{P}<0.05)$. 
biological condition of the plants and then affects the plant growth and production. Walzi et al. (2012) showed that more legume roots enhance nutrient distribution for their companion. Surpricely our data showed that the highest weight of legume roots in the legume area and quite low in grass area observed in $G$. sepium produced heighest weight of grass root. In the opposite observed in $C$. mucunoides which had high legume root weight in legume area produced low weight of grass root. The weight root or structural of roots infleuence the grass production will be discussed later in the production paragraph.

\section{Grass heights and shoots}

The grass height was significantly influenced by kind of legumes intercropped, while number of shoots in clumps was not significantly influenced by the treatments (Table 6). The number of shoots was not significantly influenced eventhough in control, the one was not intercropped which had the highest number, 30 $\%$ than the lowest. The highest $P$. maximum was observed in the one intercropped with G. sepium (160.7 $\mathrm{cm})$ followed with $C$. callothyrsus $(140.0 \mathrm{~cm})$. Grass that grew without any legume integrated showed lowest height $(98.3 \mathrm{~cm})$. The same result has been reported by Sajimin et al. (2005) and Sajimin \& Jarmani (2014) that the height of $P$. maximum is $118.2 \mathrm{~cm} /$ clump in monocultures, while intercropping with Clitoria ternatea it reaches $156.0 \mathrm{~cm} /$ clump. Intercropping with legume roots produced more grass due to the transportation of nutrients from legume areas. The same result was also reported by Ojo et al. (2013) that $P$. maximum grown faster if intercropped with a legume of Lablab purpureus compared with the one without. Onyeonogu \& Asiegbu (2013) the highest tiller number per meter square was obtained in $P$. maximum intercropping with the legumes Stylosanthes hamata.

\section{Forage production}

Legume forage production was significantly influenced by kind of legumes (Table 7). The highest forage production of the legumes was observed in $C$. mucunoides followed by the others. This plant is a shrub legume, while others are tree legumes. This experiment was more to see the grass production, however, since the legumes also share the forage production. The legume production should be noticed. Each legume species significantly produced different forage amounts due to the difference in morphology and genetics. This legume had the highest root weight in legume area (Table 4) which may take part in using the nutritional elements from the grass soil for the legume growth resulted the reduction of grass production.

Table 6. Heights and shoot numbers per clumps of grass grown integrated with legumes

\begin{tabular}{lcc}
\hline \hline Kind of legumes & Height of grass $(\mathrm{cm})$ & Number of shoots per clumps \\
\hline G. sepium & $160.7^{\mathrm{a}}$ & 9.8 \\
L. leucocephala & $135.5^{\mathrm{b}}$ & 12.3 \\
C. calothyrsus & $140.0^{\mathrm{ab}}$ & 9.5 \\
C. mucunoides & $125.5^{\mathrm{b}}$ & 10.8 \\
Control & $98.3^{\mathrm{c}}$ & 15.0 \\
\hline
\end{tabular}

Different superscript letters in the same column show significant difference $(\mathrm{P}<0.05)$.

Table 7. Forage production of legumes and P. maximum cv Riversdale intercropped with the legume roots

\begin{tabular}{lcc}
\hline \hline \multirow{2}{*}{ Kind of legumes } & \multicolumn{2}{c}{ Forage production $(\mathrm{g} \mathrm{DM} / \mathrm{pot})$} \\
\cline { 2 - 3 } & Legumes & P. maximum \\
\hline G. sepium & $21.0^{\mathrm{c}}$ & $54.7^{\mathrm{a}}$ \\
L. leucocephala & $21.1^{\mathrm{c}}$ & $50.7^{\mathrm{ab}}$ \\
C. calothyrsus & $25.4^{\mathrm{bc}}$ & $47.4^{\mathrm{ab}}$ \\
C. mucunoides & $51.9^{\mathrm{a}}$ & $30.0^{\mathrm{b}}$ \\
Control & No plants & $40.7^{\mathrm{ab}}$ \\
\hline
\end{tabular}

Different superscript letters in the same column show significant difference $(\mathrm{P}<0.05)$. 
Except for $C$. mucunoides the productions of grass intercropped with legumes were significantly higher than the control. The highest production of grass was observed at the one intercropped with G. sepium $(54.7$ $\mathrm{g} /$ plant) followed by the one with L. leucocephala (50.7 g), Caliandra $(47.4 \mathrm{~g})$, while the one with $C$. mucunoides had the lowest (30.0 g) (Table 7). The production of $L$. leucocephala was not significantly different to those of $G$. sepium and $C$. calothyrsus. The lowest grass production in the one with $C$. mucunoides might be related with short grass due to limited nutrient caused by poor quality of legume root nodules (Table 4 and 6), and the least weight of grass root. The intercropping system was not affected for the grass production, however it produced the highest legume forage.

All the effected intercroppings for grass productions were from tree legumes, those were $G$. sepium, $L$. leucocephala, and $C$. calothyrsus. The leaves of the height plants might drop to grass area and result the increase of nutritional elements in the grass soil, opposite to $C$. mucunoides which was quite short and only dropped its leaves in legume areas. All tree legumes gave higher $\mathrm{P}$ translocation higher than the negative control (Table 1). In the top of that the Rhizobium in their nodules which have the ability to fix the nitrogen will take part in improving the growth. The same results those grass biomass productions were increased by legume intercropping have been reported by Baba et al. (2011) and Abdullah et al. (2014). Darmadeh (2013) also reports that integration of peanut increases the biomass production of maize.

Intercropping with $G$. sepium gave the highest production, since it translocated the highest $\mathrm{P}$ to the soil grass, produced more effective root nodules, as well as the tallest grass and heighest grass root weight. Although the grass production was the highest, the legume production was quite low. Therefore, the total amount of the forage production from grass and legume was comparable with the one intercropped with $C$. mucunoides. This experiment was carried out in the pot or in the limited area. However, it already showed the positive effect of legume intercropping. Scaling up should be evaluated in the farm and the evaluation also should consider the forage production of the legumes.

\section{CONCLUSION}

It can be concluded from the experiment that intercropping Panicum grass with the legume roots increase $\mathrm{P}$ availability in the grass area. The $\mathrm{P}$ translocation was proved by the detection of ${ }^{32} \mathrm{P}$ radio isotop injected in the legume area. The increase of the $\mathrm{P}$ in the grass area and the activity of Rhizobium in nitrogen fixation enhanced the production of the grass.
The best grass production was observed when the grass was intercropped with G. sepium.

\section{REFERENCES}

Abdullah AA, Karti PDMH, Chozin MA, Astuti DA. 2014. Evaluasi produktivitas dan daya saing dari Brachiaria decumbens, Centrosema pubescens dan Clitoria ternatea sebagai tanaman tunggal dan campuran pola pemotongan di lahan gambut. JITV. 19:81-90.

Anantawiroon P, Tudsri S, Ishit Y. 2006. The effect of intercropping with four tropical legume species on the yield and quality of Napier grass in Thailand. Kasetsart J Nat Sci. 40:616-624.

Alan E. Richardson AE, Barea JM, McNeill AM, PrigentCombaret J. 2009. Acquisition of phosphorus and nitrogen in the rhizosphere and plant growth promotion by microorganisms. Plant Soil. 321:305-339. doi: 10.1007/s11104-009-9895-2.

Agus F, Wiratno, Suwardi. 2015. Status of Indonesian soil resources. Asian soil partnership consultation workshop on sustainable management and protection of soil resources. Bangkok (Thailand): Food and Agriculture Organization.

Baba M, Halim RA, Alimon AR, Abubakar I. 2011. Grasslegume mixture for enhanced forage production: Analysis of dry matter yield and competition indices. Afr J Agric Res. 6:5242-5250.

Belel MD, Halim RA, Rafii MY, Saud HM. 2014. Intercropping of corn with some selected legumes for improved forage production: A review. J Agric Sci. 6:48-62.

Catchpoole DW. 1988. The contribution of tree legumes to the nitrogen economy and forage production in the humid tropic (Thesis). [(New South Wales) Australia): University of New England.

Darmadeh M. 2013. Intercropping two varieties of maize (Zea mays $\mathrm{L}$ ) and peanut (Arachis hypogea $\mathrm{L}$ ): Biomass yield and intercropping advantages. Int J Agric Forest. 3:7-11.

Exner DN, Davison DG, Ghaffarzadeh M, Cruse R M 1999. Yields and returns from strip intercropping on six Iowa farms. Am J Alter Agric. 14:69-77.

Elgersma A, Schleppers H, Nassiri M. 2000 Interactions between perennial ryegrass (Lolium perenne L.) and white clover (Trifo- lium repens $\mathrm{L}$.) under contrasting $\mathrm{N}$ availability: Productivity, seasonal patterns of species composition, $\mathrm{N}_{2}$ fixation, $\mathrm{N}$ transfer and $\mathrm{N}$ recovery. Plant Soil. 221:281-299.

Eskandori H, Ghanbari A, Javonmard A. 2009. Intercropping of cereals and legumes for forage production. Nat Sci Biol. 1:7-13.

Fustec J, Lesuffleur F, Mahieu S, Cliquet JB. 2010. Nitrogen rhizodeposition of legumes: A review. Agron J Sustain Develop. 30:57-66. INRA EDP Sci. doi: 10.1051/agro/ 2009003. 
Franzini VI, Muraoka T, Mendes FL. 2009. Ratio and rate effects of ${ }^{32} \mathrm{P}$-triple super phosphate and phosphate rock mixtures on corn growth. Sci Agric Piracicaba Braz. p. 71-76.

Guo F, Yost RS, Hue NV, Evensen CI, Silva JA. 2000. Changes in phosphorus fractions in soils under intensive plant growth. Soil Sci Am. J. 64:1681-1689.

Gomez KA, Gomez AA. 1984. Statistical procedures for agricultural research. 2nd ed. IRRI. John Wiley and Sons, Inc.

Hakim N, Nyakpa NY, Lubis AM, Nugroho SG, Saul ML, Diha MA, Go BH, Bailey HH. 1986. Dasar-dasar ilmu tanah. BKS. PTN/USAID. Unila Lampung.

Horst WJ, Eticha D, Kamh M, Wang Y, Stival Da Silva AL, Stass A. 2006. Identification and characterization of aluminium resistant, phosphorus-efficient plant genotypes adapted to tropical acid soils. Hannover (Germany): Institute for Plant Nutrition, University of Hannover, Germany. Proceeding series. Management practices for improving sustainable crop production in tropical acid soil. IAEA.

Karama AS, Marzuki AR, Manwan I. 1991. Penggunaan pupuk organik pada tanaman pangan. Prosiding Lokakarya Nasional Efisiensi Penggunaan Pupuk V. Bogor (Indones): Indonesian Center for Animal Research and Development. p. 395-485.

Kalaivanan D, Sudhir K, Kotur SC. 2014. Effect of different levels and placement of ${ }^{32} \mathrm{P}$ labelled single super phosphate on absorption of phosphorus by Banana cv. robusta under high density planting. Vegetos. 27:68-75.

Latati M, Balvet D, Alkama N, Laoufi H, Drevon JJ, Gerard F, Pansu M, Ounane SM. 2014. The intercropping cowpea-maize improves soil phosphorus availability and maize yields in an alkaline soil. Plant Soil. 385:181-191.

Li L, Zhang FS, Li XL, Christie P, Sun JH, Yang SC, Tang CX. 2003 Interspecific facilitation of untrient uptake by intercropped maize and fababean. Nutr Cycl Agroeco. 65:61-71

Mulyani A, Hikmatullah, Subagyo H. 2004. Karakteristik dan potensi tanah masam lahan kering di Indonesia. Prosiding Simposium Nasional Pendugaan Tanah Masam. Bogor (Indones): Pusat Penelitian dan Pengembangan Tanah dan Agroklimat. p. 1-32.

Mutegi JK, Mugendi DN, Verchot LV, Kung'u JB. 2008. Combining Napier grass with leguminous shrubs in contour hedgerows controls soil erosion without competing with crops. Agroforest Syst Springer Sci. 13 p.

Ojo VOA, Dele PA, Amole TA, Anele UY, Adeoye SA, Hassan OA, Olanite JA, Idowu OJ. 2013. Effect of intercropping Panicum maximum Var. Ntchisi and Lablab purpureum on the growth, herbage yield and chemical composistion of Panicum maximum var. Ntchisi at different harvesting times. Pak J Biol Sci. 16:1605-1608.

Richardson AE, Barea JM, McNeill AM, Prigent-Combaret C. 2009. Acquisition of phosphorus and nitrogen in the rhizosphere and plant growth promotion by microorganisms. Plant Soil. 321:305-339. doi: 10.1007/s11104-009-9895-2.

Sajimin, Jarmani SN. 2014. Pengaruh interval panen terhadap produksi kualitas rumput $P$. maximum cv Purple Guinea sebagai pakan ternak di Kabupaten Blora. Kaiin EM, Tappa B, Widyastuti Y, Said S, Agung PP, editors. Prosiding Seminar Nasional Peran Bioteknologi dalam Peningkatan Populasi dan Mutu Genetik Ternak Mendukung Kemandirian Daging dan Susu Nasional. Bogor (Indones): Lembaga Ilmu Pengetahuan Indonesia. p. 110-117.

Onyeonogu CC, Asiegbu JE. 2013. Harvest frequency effect on plant height, grass tiller production, plant cover and percentage dry matter production of some forage grass and legumes in the derived Savannah Nigeria. Afr J Agr Res. 8:608-618.

Sajimin, Sutedi E, Purwantari ND, Prawiradiputra BR, 2005. Agronomi rumput benggala (Panicum Maximum Jacq) dan pemanfaatannya sebagai rumput potong. Subandriyo, Diwyanto K, Inounu I, Prawiradiputra BR, Setiadi B, Nurhayati, Priyanti A, editors. Prosiding Lokakarya Nasional Tanaman Pakan Ternak. Bogor (Indones): Pusat Penelitian dan Pengembangan Peternakan. p. 121-129.

Saidu A, Abayomi YA. 2015. Interactive effects of organic and inorganic fertilizers on the performance of Upland Rice (Oryza sativa 1.) Cultivars. Int J Agr Sci. 5:399-406.

Walzi KP, Rasmussen J, Jensen HH, Eriksen J, Soegard K, Rasmussen J. 2012. Nitrogen transfer from forage legumes to nine neighbouring plants in a multi-species grassland. Plant Soil. 350:71-84.

Xiao Y, Li L, Zhang F. 2004. Effect of root contact on interspecific competition and $\mathrm{N}$ transfer between wheat and fabean using direct and indirect $15 \mathrm{~N}$ techniques. Plant Soils. 262:45-54. 